Maciej Rak

Uniwersytet Jagielloński, Kraków

maciej.rak@uj.edu.pl

\title{
SŁOWNICTWO PODHALAŃSKIE W ETYMOLOGICZNYM SŁOWNIKU JĘZYKA POLSKIEGO ANDRZEJA BAŃKOWSKIEGO*
}

Słowa klucze: gwara podhalańska, etymologia, słowniki etymologiczne Keywords: Podhalan dialect, etymology, etymological dictionaries

\section{Uwagi wstępne}

Słowniki etymologiczne można podzielić na trzy typy. Najbardziej pracochłonne są słowniki objaśniające całość leksyki (bez oczywistych derywatów, neologizmów i zapożyczeń specjalistycznych), czyli kilkadziesiąt tysięcy leksemów. Takim opracowaniem jest nieukończony (obejmujący hasła od A do $Ł$, do łżywy) słownik Franciszka Sławskiego (SESł).

Drugim, najczęściej spotykanym rodzajem słowników etymologicznych są opracowania objaśniające od kilku do kilkunastu tysięcy wyrazów. Przykładem może być zawierający około 4600 artykułów hasłowych słownik Wiesława Borysia (SEBor). Trzeci typ słowników to opracowania popularne, przeznaczone dla szerokiego odbiorcy, np. słowniki Aleksandra Brücknera (SEBr) i Krystyny Długosz-Kurczabowej (WSE-HJP).

* Niniejszy artykuł powstał kilka miesięcy przed odejściem Profesora Andrzeja Bańkowskiego. Niestety, na ewentualną polemikę autor liczyć już nie może. Red. 
Poza tymi podziałami znajduje się Etymologiczny słownik języka polskiego Andrzeja Bańkowskiego (SEBań). Jest to opracowanie bardzo obszerne (w dwóch tomach wraz z odsyłaczami znalazło się 18 ooo haseł), obejmujące zarówno leksykę dawną, jak i współczesną, także przejrzyste słowotwórczo i znaczeniowo derywaty, słownictwo specjalistyczne i zapożyczenia ${ }^{1}$, słownictwo potoczne i niektóre dialektyzmy ${ }^{2}$. SEBań podobnie jak SESł nie został ukończony (drugi z czterech planowanych tomów został doprowadzony do litery P, do hasła pyza). Zaważyły na tym krytyczne opinie niektórych językoznawców, zwłaszcza członków Rady Języka Polskiego PAN³.

Niniejszy artykuł dotyczy leksyki podhalańskiej w SEBań. Także inne słowniki etymologiczne (SEBr, SESł i SEBor) uwzględniają ten typ słownictwa, ale w mniejszym stopniu niż słownik Bańkowskiego. Jedynym większym opracowaniem, które w całości poświęcono pochodzeniu słownictwa gwar góralskich, jest trzecia część monografii Wandy Herniczek-Morozowej Terminologia polskiego pasterstwa górskiego Pochodzenie stownictwa pasterskiego polskiego Podkarpacia (na podstawie etymologii, historii i geografi gwarowej wybranych wyrazów) (Her II).

W SEBań znalazło się kilkanaście słów pochodzących z gwar góralskich: ceper, cetyna, ciupaga, cucha (cuha), gazda, hala, harnaś, juhas, kierdel, kierpce, moskal, oszczepek i perć 4 . Przy charakterystyce tej leksyki wziąłem pod uwagę trzy elementy hasła słownikowego: informacje o pochodzeniu słów, datowanie, definicje oraz inne komentarze odautorskie.

\section{Pochodzenie leksyki podhalańskiej}

Większości słownictwa podhalańskiego Bańkowski przypisał status neologizmów opartych na leksyce z innych gwar karpackich, zwłaszcza słowackich. Jak czytamy w SEBań, propagatorami tych słów byli Seweryn Goszczyński, Wincenty Pol, Władysław Orkan oraz inni poeci i pisarze przyjeżdżający na Podhale w pierwszej połowie XIX w. Podstawowa trudność w badaniu leksyki podhalańskiej polega więc na tym, że:

Dziś trudno już odróżnić, co w karpackim słownictwie pasterskim autentyczne, a co „wkłamane” juhasom „w pieśniach” przez wiele pokoleń literatów-maniaków, „góralomanów" (SEBań I: 195).

1 Duża liczba zapożyczeń wynika prawdopodobnie z tego, że Bańkowski opracował pochodzenie wyrazów (etymologię) do SWOSob.

2 Jak czytamy we wstępie do SEBań (I: VIII), znajdziemy w nim „[...] głównie słownictwo literackie i potoczne warstw wykształconych, ale też te z wyrazów uważanych za gwarowe lub slangowe, które znalazły odbicie w literaturze albo są przydatne do objaśnienia wyrazów literackich".

3 Zob. http://www.rjp.pan.pl/index.php?option=com_content\&view=category\&id=51:dyskusja-nadqetymologicznym-sownikiem-jzyka-pol\&Itemid=50\&layout=default, 1 XII 2013).

4 Pominąłem dość liczną grupę archaizmów, które są używane w gwarze podhalańskiej, ale nie są z nią identyfikowane w SEBań, np. gody 'święta Bożego Narodzenia', drzewiej 'dawniej', dudek 'potoczna nazwa monety trzygroszowej z wizerunkiem orła w koronie podobnego do dudka'. 
Przyjrzyjmy się kilku przykładom:

1. Ciupaga 'w Tatrach rzekoma nazwa góralskiej pasterskiej laski z siekierką, zmyślona przez S. Goszczyńskiego [...], jak wiele innych u niego „góralizmów”; chyba przeinaczenie gw. karpackiego ciumaga, z rum. ciomág n. 'pałka, maczuga', przez wtórne nawiązanie do ciupać' (SEBań I: 195).

Inaczej ciupagę objaśniał F. Sławski (SESł I: 105). Podał, że pochodzenie tego wyrazu jest niejasne, a biorąc pod uwagę jego znaczenie i zasięg geograficzny, należy w nim widzieć zapożyczenie być może południowosłowiańskie (por. bułg. tojága 'laska'). Związek z czasownikiem ciupać 'słabo rąbać, słabo bić' według tego badacza jest etymologią ludową, jednak takie objaśnienie znajdziemy w SEBr (s. 65).

„Zmyślenie [ciupagi - M.R.] przez S. Goszczyńskiego” jest niemożliwe, na co wskazuje między innymi zasięg geograficzny tego rzeczownika (informacje o geografii ciupagi znajdziemy w SKarł (I: 242), AJPP (m. 172), ODA VII (m. 701), Her II (s. 97) oraz w SGP). Ciupaga w gwarach polskich ma trzy znaczenia: 1) 'laska pasterska zakończona toporkiem, na drugim końcu ostro okuta, niekiedy ozdobiona', 2) 'rodzaj siekiery osadzonej na długim toporzysku', 3) 'kij do podpierania się' (SGP IV: 436-437). W pierwszym znaczeniu ciupaga jest notowana przede wszystkim w gwarze podhalańskiej (Kosiński 1884: 274; Kryński 1884: 213; Bubak 1966: 21, 27; HodSG 22; ZborSGZ 37), orawskiej (KąśSGO 86) i spiskiej (Bubak 1972: 77). W sąsiednich gwarach ciupaga pojawia się w drugim znaczeniu, również jako synonim siykiyrki albo (w Zawoi i Jaworkach) walaski (AJPP, m. 172). Pod Krakowem, w okolicach Bochni, Wadowic i Ropczyc, ciupaga nabiera nacechowania negatywnego i jest tam pogardliwą nazwą tępej siekiery (Kosiński 1887: 39; SKarł I: 242; SGP IV: 437). W trzecim znaczeniu ciupage zanotowano w Sękowej (pow. gorlicki) (SGP IV: 437).

Opisane wyżej ograniczenia geograficzne i zmiany semantyczne są wynikiem przynależności ciupagi do terminologii pasterskiej - znaczenia tego typu wyrazów ulegają znacznym przekształceniom w gwarach oddalonych od Podtatrza.

2. Hala 'pastwisko w Tatrach wysoko położone, powyżej lasów' 1832, w tej postaci i w tym znaczeniu wprowadził S. Goszczyński, na podstawie gwarowego hola (ze słowac.) o znaczeniu topograficznym 'wierzchowisko doliny tatrzańskiej, gołe' (powyżej granicy lasów) [...]. Za wiarygodnym świadectwem Staszica (1815), który badając dokładnie wierzchołki Tatr spędził na nich wiele letnich miesięcy, ludową w Tatrach nazwą pastwiska wysokogórskiego było (na przełomie XVIII i XIX w.) jednak polana (nie hola, holica). Słowo w wersji Goszczyńskiego spopularyzował W. Pol i inni literaci, z których wzmianki godzien zwłaszcza M. Bałucki ze swoim niezapomnianym Góralu, czy ci nie żal odchodzić od... hal (1864)' (SEBań I: 514).

Nie wiadomo, na jakiej podstawie i dlaczego Bańkowski właśnie Goszczyńskiemu przypisał wprowadzenie i popularyzowanie rzeczownika hala. Warto jednak dodać pewne uściślenie - hala nie jest synonimem polany. Hala to 'wysokogórskie 
pastwisko powyżej granicy lasu', a polana to 'pastwisko śródleśne powstałe w wyniku karczunku lub wypalenia' (por. w tym kontekście dawną, do lat 40. XIX w. nazwę Kościelisk - Polany (Nitsch 1933)). Nie tylko SEBań, ale także AJPP (m. 329) błędnie przypisuje tym dwóm wyrazom relację synonimii. W wyniku metonimii w gwarze podhalańskiej hále (plurale tantum) jest nazwą Tatr (od wyrażenia przyimkowego pod hálami pochodzi choronim Podhale).

Zestawienie różnych etymologii hali znajdziemy w Her II (s. 106-107) oraz w artykule Janiny Szewczyk (1960), według której hala nie jest zapożyczeniem słowackim, lecz kontynuantem wyrazu rodzimego. Trudno zgodzić się z tą opinią, mając na uwadze znaczenie, przynależność do terminologii pasterstwa wysokogórskiego i geografię hali. Z ODA VII (m. 693) wynika, że wyraz ten jest znany tylko w gwarach północnej Słowacji oraz południowej Małopolski, jest to więc niewątpliwie pożyczka słowacka (tak SESł (I: 393-394), w SEBr (s. 167) pojawiła się błędna informacja, że hala pochodzi z języka czeskiego). Hala jest formacją odprzymiotnikową (por. słowac. holá 'goła (przym. r. ż.)') z nieumotywowanym etymologicznie a pochylonym, w polszczyźnie ogólnej hiperpoprawnie utożsamionym z a jasnym, co w konsekwencji daje homonim z hala 'duża sala, obszerne pomieszczenie'. Na o wskazuje forma D. $1 \mathrm{~m}$. do hól, ujawniająca wymianę $o: o ́$.

3. Harnaś 'herszt legendarnych w Tatrach zbójników’ 1900, twór sztuczny góralomanów polskich, oparty na słowac. gw. harnad', co przeinaczeniem (według adi. harny) węg. had-nagy 'porucznik' (SEBań I: 522).

Ten rzeczownik nie ma jednoznacznie ustalonej etymologii (por. zestawienie różnych objaśnień etymologicznych w: Her II: 108). W SEBr znajdujemy podobne hasło - harnasz, które zostało wyprowadzone z niem. Harnasch i Harnisch. W dalszej części hasła czytamy, że te niemieckie wyrazy pochodzą z celtyckiego 'o żelaznej zbroi, ograniczonej w końcu do pancerza', por. franc. harnais 'o zbroi końskiej' (SEBr: 169). Rumuńskie arnaş Dumitru Crânjală (1938: 168) nieprecyzyjnie objaśnia jako wyraz pochodzący z jakiegoś innego języka romańskiego (może francuskiego?) lub łaciny. SESł, SEBor i SWOKop nie uwzględniają hasła harnaś. SWOSob (s. 418) objaśnia, że rzeczownik harnaś to być może pożyczka z węg. hármas 'trzeci' z wtórnym - $n$ - według gw. harny 'piękny, dumny'. Objaśnienie takie jak SEBań (I: 118) wcześniej podał Jan Reychman (1951: 206), wskazując na pośrednią formę harnadziej ' dowódca bandy zbójów', zanotowaną w kartotece SGP.

4. Perć 'ścieżka stroma w Tatrach' około 189o, termin propagowany wściekle przez góralomaniaków-taterników (używa go Matlakowski, Tetmajer, Kasprowicz, Żeromski, Sienkiewicz, Kossak-Szczucka i in.), gw. nowotarskie pyrć, słowac. prt' f. 'ścieżka górska' [...] (SEBań II: 528). 
Geografia rzeczownika perć została ustalona w AJPP (m. 338). Obejmuje ona tereny bezpośrednio przylegające do Tatr (Podhale, Orawa, Spisz), a także w niedalekiej odległości od nich - Ujsoły, Zawoja, Tylmanowa i Jaworki. W. Herniczek-Morozowa (Her II: 145) informuje jednak, że na Spiszu nie zanotowała tego wyrazu. W ODA VII (m. 753) formy pyrć, perć, prt', pr'tina zostały podane z terenu Polski, Czech (Morawy), Słowacji i Serbii (jeden punkt - Првонек).

W SEBr (s. 402), podobnie jak w SEBań, czytamy, że omawiany rzeczownik w polskich gwarach jest pożyczką słowacką (SEBr uwzględnia też możliwość bezpośredniej kontynuacji psł. prt' ${ }^{\prime}$ ). Na słowackie zapożyczenie do gwar czeskich, por. formy prt', pirt', pirta, pirc, pyrt', wskazuje też Václav Machek (Mach 487). Jednak mapa numer 753 z ODA oraz formy bułg. пъртина 'ścieżka w śniegu', rum. pîrtie 'ścieżka w górach' i ukr. nepmo/nupms 'ts.' przemawiają za południowosłowiańskim pochodzeniem perci i rozprzestrzenieniem się tego wyrazu w wyniku migracji wołoskich (podobnie objaśnia perć Gołąb (1952: 207)). Miklosich (1886: 243-244), Младенов (1941: 539), Фасмер (III: 246), Skok (III: 58-59) i ECУM (IV: 357) wiążą prtt'z czasownikiem * perti 'iść; przesuwać się do przodu, nie zważając na przeszkody’. Z kolei Machek (Mach 487) sugeruje związek z lac. portus, porta.

5. Cetyna 'igliwie świerkowe' 1900. [...] Ów postulowany i propagowany przez „organistów" licznych i poniektórych przychylnych sprawie marksistów (jak Gałecki-Strug) osobny język Podhalan oparto w zasadzie na mieszance gwar nowotarskiej i beskidzkiej, ale też (staraniem Orkana) wzbogaconej licznymi pożyczkami z innych gwar karpackich (dla niepoznaki umyślnie przeinaczonymi), zwłaszcza słowackich i rusnackich (dziś łemkowskich), do których należy też cetyna, zamiast rusnackiego ščetýna (posłyszanego z ust bezzębnej babki) (SEBań I: 118-119).

SEBań jest jedynym, który wskazuje na rusnackie (łemkowskie) pochodzenie $c e-$ tyny. SEBr (s. 59), a także Her II (s. 95) objaśniają cetynę w gwarach Podtatrza jako pożyczkę z gwar słowackich, por. četína (čačína). Her II (ibid.) uściśla, że na Żywiecczyźnie i w Cieszyńskiem cetyna jest prawdopodobnie pożyczką z dialektu morawskiego języka czeskiego (četina). Świadectwa z języków południowosłowiańskich (bułg. четина, serb. четина, chorw. сеtina, mac. четина), języka rumuńskiego (cétina 'choina, cetyna', które D. Crânjală (1938: 242) uznaje za pożyczkę słowiańską) oraz ukraińskiego (чатина) wskazują podobnie jak w przypadku perci na pośrednictwo wołoskie. Zasięgowi geograficznemu cetyny w gwarach polskiego Podkarpacia poświęcono trzy mapy w AJPP (m. 310, 312, 313). Hasło to zostało także umieszczone w ODA IV (m. 396) z następującymi znaczeniami: 1) 'gałązka drzewa iglastego', 2) 'choina', 3) 'twarda trawa', 4) 'szczecina'. SEBr (s. 543) objaśnia, że cetyna ma wspólny rdzeń ze szczecią/szczecina (tak samo Фасмер (IV: 505) і ЕСУM (VI: 506-507), por. też Младенов (1941: 684) і Mach 625). 
6. Ceper (około 1930) gw. nowotarskie (wcześniej spiskie) pogard. 'o głupim próżniaku miejskim przyjeżdżającym w góry nie wiadomo po co’; słowac. dial. čepyr 'kuglarz wędrowny, objeżdżający jarmarki', skrót z węg. csepürágó 'kuglarz' (por. csepü 'pakuły’, rángi ‘żuć) (SEBań I: 117).

Słowo ceper nie zostało uwzględnione w SESł, SEBr, Her I, II, nie znajdziemy go też w AJPP ani w ODA. Powstało kilka etymologii ludowych tego wyrazu. Według najpowszechniejszej ceper to nazwisko inżyniera, który budował kolej do Zakopanego. W WET (s. 136) czytamy jednak, że ceper to zniekształcona postać wyrazu saper. Być może na takie objaśnienie wpłynął Dem (s. 240), w którym znajdujemy formę caper.

Ceper został uwzględniony w SWOKop (s. 91). Z opracowania tego dowiadujemy się, że jest to pożyczka z gwar wschodniosłowackich od teper 'teraz'. Na słowackie pochodzenie omawianego słowa wskazują też SEBań oraz SWOSob (s. 163). W obydwu słownikach ustalono jednak, że ceper ostatecznie pochodzi z języka węgierskiego.

Polemiczne w SEBań jest jednak pytanie o to, jakie gwary uczestniczyły w zapożyczaniu cepra, pośrednictwo spiskie bowiem nie znajduje potwierdzenia w opracowaniach naukowych. Być może na taki właśnie trop naprowadziła Bańkowskiego słuszna jak można sądzić - opinia, że pożyczki słowackie docierały na Podhale głównie przez gwary spiskie i orawskie, które były bezpośrednio wystawione na wpływy słowackie. Jednak opinii, że pierwotnie ceper był wyrazem spiskim, nie da się naukowo obronić.

7. Oscypek 'serek owczy o kształcie grotu oszczepu' 1800 (Linde = ser owczy góralski w tworzydełkach wyciskany); gw. oscypek = oscépek; w znaczeniu 'mały oszczep' u Stryjkowskiego 1582 (SEBań II: 455-456).

Oscypek, co może zaskakiwać, nie został uwzględniony w AJPP. W ODA III (m. 214) hasłu oščipek przypisano następujące znaczenia: 1) 'wędzony ser owczy' (Podtatrze i Żywiecczyzna, Morawy i północna Słowacja), 2) 'wędzony ser owczy uformowany w figurki np. zwierząt' (zakres geograficzny taki jak w przypadku znaczenia 1), 3) 'rodzaj pączka ze słodkim bądź słonym nadzieniem' (z Serbii - yumunaк, Bośni i Hercegowiny oraz Chorwacji - uštipak), 4) 'placek owsiany pieczony na blasze' (Ukraina - ощипок/ощinoк: gwary zakarpackie, bojkowskie, huculskie i naddniestrzańskie), 5) 'rodzaj kołacza z serem' (Ukraina - gwary naddniestrzańskie), 6) 'kawałek czegoś' (Ukraina - gwary naddniestrzańskie i pokucko-bukowińskie). Tych kilka znaczeń można podporządkować dwóm, które różni geografia: 1) 'ser owczy' (Karpaty Zachodnie), 2) 'pieczywo' (Karpaty Wschodnie i zachodnia część Bałkanów).

W SEBań oscypek został uznany za derywat od rzeczownika oszczep (gw. oscep/ oscyp). Na takie objaśnienie być może wpłynął SKarł (III: 477), w którym oszczepek 'ser baryłkowaty z wyciskanymi ozdobami' jest podhasłem do oszczep. Jest to jednak etymologia ludowa. Kwestii pochodzenia oscypka nie rozstrzyga też Her II (s. 141), informując jedynie, że na Podtatrzu być może jest to pożyczka z gwar słowackich (oštiepok), a na Żywiecczyźnie - z Moraw (oštípek, oštěpka 'suszone owoce rozszczepione na części’). Z kolei Machek podaje za Pavlem O. Hviezdoslavem, że słowac. oštiepok 
wziął nazwę od tego, że bacowie wycinali (štípali) na grudach sera podobizny ptaków i jagniąt (Mach 626).

Warto jednak zaproponować inną etymologię, która uwzględnia homonimię:

1. Oscypek jako ‘ser owczy’. Punktem wyjścia jest tu psł. *ščepiti/ščepati< pie. ${ }^{*}(s) k e p$ (SEBr 543; Фасмер IV: 502-503; Mach 626; SEBor 596; ECУM VI: 504-505) oznaczające 'łupać, rozłupywać, rozszczepiać'. Najprawdopodobniej oscypek oznaczał pierwotnie drewnianą formę ( $\mathrm{z}$ drewna jesionowego lub lipowego), składającą się z dwóch jednakowych elementów, w której odciskano ser. Ogólnopolskim odpowied nikiem byłby więc rozszczepek - taka postać wyjaśnia brak archaizmu podhalańskiego w oscypku (także słowacki oštiepok potwierdza obecność etymologicznego e w śródgłosie). Semantyka przedrostka roz-wskazuje na dwuelementowość przedmiotu, o którym mowa, albo na działanie, które prowadzi do rozłupania przedmiotu (por. podhalańskie formy bez archaizmu oscypać, oscypić (sie) 'rozłupać', oscypiony 'rozłupany', HodSG 288). Takie znaczenie ujawnia się również w przykładach z Moraw (patrz wyżej) oraz z ODA III (m. 214) - oщ,unoк 'rozszczepiona deska, rozszczepione drewno' (jeden punkt z gwar pokucko-bukowińskich). Wtórnie (w wyniku metonimii) oscypkiem nazwano ser odciskany w oscypku. Po takiej zmianie semantycznej na oznaczenie drewnianej formy zaczęto używać wyrazu foremka (Her I: 63) bądź derywatu od oscypek - oscypiárka (ibid.: 133). Za taką interpretacją przemawiają inne nazwy serów owczych lub mieszanych owczo-krowich, m.in. baranek (ibid.: 37-38), kohutek (ibid.: 92), kaczka (ibid.: 82), ryba (ibid.: 162), serce (ibid.: 166). Wymienione rzeczowniki mają dwa znaczenia: 1) 'serek', 2) 'drewniana foremka do formowania takiego serka'.

2. Dla haseł ощиипок, уштипак, uštipak w znaczeniu 'pieczywo' punktem wyjścia jest psł. ‘ščipati < pie. * ${ }^{*} k e i-p-{ }^{*}{ }^{*}$ skei- $b$ - 'ciąć, oddzielać, odłączać, odrywać, odłamywać kawałek czegoś' (SEBr 545-546; Фасмер IV: 507; Mach 629; Skok III: 414-415; SEBor 60o; ECyM VI: 509). Na te znaczenia bezpośrednio wskazuje jedno z objaśnień zanotowanych w ODA z gwar naddniestrzańskich - oщun ок 'odłamany kawałek chleba'. Pośrednio za taką hipotezą przemawia też bałkański ušttipak (derywat od czasownika štípati, por. Skok III: 414), a dokładniej sposób, w jaki przygotowuje się to pieczywo. Według przepisów kulinarnych od ciasta przeznaczonego na uštipci odrywa się kolejne porcje i smaży na głębokim oleju. W podobny sposób można też objaśnić gw. ukr. oщunoк 'placek owsiany pieczony na blasze', który jest jedzony w taki sposób, że odrywa się od niego kawałki (w ECYM (IV: 246) ощципк został odesłany do hasła щ̧ипати (VI: 509)).

Jak jednak objaśnić oщunoк 'kołacz z serem’? Kluczem znów jest geografia tego wyrazu. We wskazanym znaczeniu ощциюк jest znany w gwarach naddniestrzańskich. Jak już wcześniej pisałem w odniesieniu do ciupagi, słownictwo karpackie w gwarach oddalonych od Karpat zmienia znaczenie. W tym przykładzie nadal chodzi o pieczywo, ale już inne. 


\section{Datowanie słownictwa}

Do warsztatu etymologa należy nie tylko określenie pochodzenia danego wyrazu, ale także jego datowanie. Jak czytamy we wstępie do SEBań (I: XXIII):

Wadą główną niektórych dawnych słowników etymologicznych jest brak datowania cytowanych form albo ich datowanie sporadyczne i nie dość wiarygodne [...]. Jeśli idzie o wyraz pierwotnie dialektalny bądź regionalny, z czasem dopiero rozpowszechniony w innych dzielnicach Polski, wskazuje się zwykle czas jego pierwszego poświadczenia lokalnego i czas (przybliżony) jego rozpowszechnienia.

Przy każdym z góralskich wyrazów znajduje się data precyzująca czas pierwszego poświadczenia, por.: ceper (około 1930), cetyna (1900), ciupaga (1832, S. Goszczyński), czucha (XIX-2), gazda (1580), hala (1832, S. Goszczyński), harnaś (1900), juhas (1832, S. Goszczyński), kierdel (1902), kierpce (1902), moskal (1534), oszczepek (1809, Linde), perć (około 189o).

Pierwsza notacja kilku podhalańskich słów została przypisana Dziennikowi podróży do Tatrów Goszczyńskiego (1853), stąd data 1832 r. (dokładniej rzecz ujmując, jest to data napisania Dziennika, który w całości został opublikowany w 1853 r.). Pierwsze poświadczenie oszczepka Bańkowski przypisuje słownikowi Lindego, z kolei inne słowa datuje bez wskazania źródła. Są tu co prawda określenia mniej precyzyjne, sygnalizowane przyimkiem około (perć około 1890, ceper około 1930), ale obok nich pojawiają się konkretne daty: 1900 (harnaś, cetyna), 1902 (kierdel, kierpce). Ze względu na brak w SEBań bibliografii czy wykazu źródeł nie wiadomo, na jakiej podstawie te daty zostały ustalone (może intuicyjnie, ale jeśli tak, to dlaczego tak dokładnie, zwłaszcza w przypadku roku 1902).

Dokładniejsze przyjrzenie się zaproponowanemu tu datowaniu przekonuje, że autor słownika nie uwzględnił kilku ważnych opracowań dotyczących gwary podhalańskiej. Cepra nie można datować na rok około 1930, bowiem wyraz ten został zanotowany (w nieco zmienionej formie - caper) już w Słowniku gwary podhalskiej Bronisława Dembowskiego (Dem), czyli w roku 1894. W zbiorze tym znajdziemy również harnasia (błędnie datowanego na 1900 r.). Z kolei wyrazy perć (około 189o) i kierdel (1902) pojawiają się w opracowaniu z 1845 r. - Pieśni ludu Podhalan, czyli górali tatrowych polskich Ludwika Zejsznera (1845). Kierpce (według SEBań - 1902) poświadcza Walery Eljasz-Radzikowski (1874: 258), a cetynę (1900) - Władysław Kosiński (1884: 273).

\section{Definicje i komentarze odautorskie}

Zastosowane w SEBań definicje i komentarze odautorskie ujawniają osobowość autora, a przy tym czasem są błędne. Tak jest na przykład z moskalem, przy którym w SEBań (II: 212) znajdujemy następującą definicję: 'placuszek pieczony z zakwaszonego ciasta', 
podczas gdy moskal jest pieczony z ciasta niezakwaszanego i, co ważne, z mąki owsianej. W innych definicjach przebrzmiewa nastawienie prześmiewczo-bagatelizujące, por. cytowane wyżej hasła ceper i ciupaga. Czasem definicja ma wspomóc wywód etymologiczny, jak w przypadku oscypka objaśnionego jako 'serek owczy o kształcie grotu oszczepu'.

Komentarze odautorskie podważają dotychczasową wiedzę na temat historii Podhala i gwary podhalańskiej. Zwróćmy uwagę na dwa przykłady:

Cetyna [...] jedno z grupy sztandarowych słów pseudojęzyka podhalańskiego (pothalanische Goralenvolkssprache), o którym etymologom tylko satyry pisać. Twórcą i propagatorem pierwszym tego i tych słów oraz narodu góralskiego z prawem do własnego języka był F. Smaciarz-Smreczyński-Orkan 1875-1930, płodny literat, dzielny demagog i socjalista nacyjny. On to wszystkie w Tatrach i Gorcach (pod reglami i między reglami) pasterskie polany (u Staszica tylko tak zwane, nigdy inaczej) przemianował na hale (niby fabryczne), gdzie proletariat juhaski fabrykuje dla burżujów bryndzę. Odtąd wyziewy z tych fabryczek serowarskich wiatr halny (albo halniak) niesie po całym międzygórskim starostwie nowotarskim (pierwotnie ludźmierskim), przemianowanym z tej wiaternej przyczyny na Podhale, gdzie odtąd żyją Podhalanie, najzamożniejsi w całej „Golicyi i Głodomeryi”, ale pośród swoich tłustych baranów głodujący na cześć Marksa i Engelsa (za co ich sam Lenin odwiedził), a przełęczy bronią wyborowi strzelcy podhalańscy (zastąpiwszy cesarsko-królewskich alpejskich), interesów bacowskich Gazeta Podhalańska, organ Związku Podhalan. Ów postulowany i propagowany przez „orkanistów” licznych i poniektórych przychylnych sprawie marksistów (jak Gałecki-Strug) osobny język Podhalan oparto w zasadzie na mieszance gwar nowotarskiej i beskidzkiej, ale też (staraniem Orkana) wzbogaconej licznymi pożyczkami z innych gwar karpackich (dla niepoznaki umyślnie przeinaczonymi), zwłaszcza słowackich i rusnackich (dziś łemkowskich), do których należy też cetyna zamiast rusnackiego ščetýna (posłyszanego z ust bezzębnej babki). Od tego, tak eufonicznego nowotworka góralomaniackiego wzięły już swoje miano naukowe dwa najszkodliwsze dla igliwia owady: cetyniak i cetyniec. Czekamy, czy kto raczy sprzyjający owym szkodnikom wiater halny przemianować na orkaniec (brzmiący po cetynie) (SEBań I: 118-119).

Hala [...] To Goszczyński także od swojego „alańskiego" hala urobił nazwę Podhale, obejmującą na jego życzenie cały obszar byłego starostwa nowotarskiego. Nowo mianowaną prowincję, kwitnącą nadmiarem folkloru (więc szlakiem „alanizatora" coraz częściej nawiedzaną przez alkoholików i syfilityków) zaludnili Podhalanie, tak rośli i dzielni, że podhalański (nie byle podhalski) znaczy dziś plenus virtute militari, a stąd dalej podhalańszczak ‘żołnierz polskiej piechoty górskiej’ (rzadko walczącej w górach, ale zawsze wyborowej, dzielnej i strojnej) (ibid.: 514).

Z tych komentarzy dowiadujemy się, że gwara podhalańska to w dużej mierze twór pisarzy i poetów, co - jak starałem się pokazać wyżej - nie jest prawdą. W gwarze tej są obecne karpatyzmy, ale nie za sprawą przemyślanej działalności konkretnych osób, lecz w wyniku oddziaływania kultury wołoskiej i terminologii pasterskiej, najczęściej 
pochodzenia bałkańskiego. Wreszcie, nie jest to pseudojęzyk czy też osobny język Podhalan, lecz gwara.

Z historii Podhala Bańkowski wypunktował to, czym górale się nie chwalą Goralenvolk (stąd uwaga o pothalanische Goralenvolkssprache) i pobyt Lenina w Białym Dunajcu w latach 1913-1914. Z kolei o pierwszych turystach przyjeżdżających na Podhale dowiadujemy się, że byli to alkoholicy i syfilitycy. Te i inne niemerytoryczne uwagi dowodzą, że autor słownika miał nieprzychylne nastawienie do Podhala.

\section{Podsumowanie}

Zestawiając materiał z atlasów i słowników gwarowych, starałem się wykazać, że etymologie leksyki podhalańskiej umieszczone w SEBań w dużej części są niedokładne albo nawet błędne. W drugim przypadku zaproponowałem własne objaśnienia. Warto jednak dla przeciwwagi podkreślić nowatorstwo SEBań widoczne na przykład przy haśle moskal (SEBań II: 212) 'placek owsiany pieczony na blasze'. Jest to bowiem jedyne opracowanie, które komentuje pochodzenie tego słowa (abstrahuję tu od etymologii ludowej podawanej przez górali ${ }^{5}$ ). Według SEBań moskal to staropolska (notowana już w latach $1543,1566,1568)$ nazwa 'placuszka', jedynie przypadkowo podobna do etnonimu.

Uwagi, które umieściłem w niniejszym artykule, przekonują, że gwara podhalańska ze względu na bogactwo słownictwa nienotowanego w innych gwarach polskich zasługuje na osobny słownik etymologiczny. Wzorem dla takiego opracowania mógłby być na przykład Słownik etymologiczny kaszubszczyzny Wiesława Borysia i Hanny Popowskiej-Taborskiej (SEK).

\section{Wykaz skrótów}

bułg. $=$ bułgarski, chorw. $=$ chorwacki, franc. $=$ francuski, gw. $=$ gwarowy, łac. $=$ łaciński, mac. $=$ macedoński, niem. $=$ niemiecki, pie.$=$ praindoeuropejski, psł. $=$ prasłowiański, rum. $=$ rumuński, serb. = serbski, słowac. $=$ słowacki, ukr. = ukraiński, węg. = węgierski.

\section{Literatura}

AJPP: M. Małecki, K. Nitsch, Atlas językowy polskiego Podkarpacia, Kraków 1934. Buвак J., 1966, Teksty gwarowe ze wsi Zab w powiecie nowotarskim, „Zeszyty Naukowe UJ” XCVIII, „Prace Językoznawcze” 12, Kraków.

5 Górale wiążą moskala z etnonimem Moskal 'pejoratywnie o Rosjaninie' w następujący sposób: podczas I albo II wojny światowej podpatrzyli u Rosjan, jak się przygotowuje oraz wypieka moskále, i w ten sposób utworzyli nazwę. Łatwo zdyskredytować to objaśnienie - rzeczownik moskál/moskálicek został zanotowany przez L. Zejsznera (1845: 77, 131). 
Bubak J., 1972, Spiskie teksty gwarowe z obszaru Polski, „Zeszyty Naukowe UJ” CCLXXVIII, „Prace Językoznawcze” 36, Kraków.

CrÂnjală D., 1938, Rumunské vlivy v Karpetech, Praha.

Dem: B. Dembowski, Słownik gwary podhalskiej, „Sprawozdania Komisji Językowej Akademii Umiejętności” V, 1894, s. 339-444, [przedruk w:] J. Okoniowa (red.), Studia dialektologiczne III, Kraków 2006, s. 233-342.

Eljasz-Radzikowski W., 1874, Szkice z podróży w Tatry, Poznań.

ЕСУМ: О.С. Мельничук (red.), Етимологічний словник української мови, t. I-VI, Київ 1982-2012.

Фасмер: М. Фасмер, Этимологический словарь русского языка, Москва 1987.

Go£Ąв Z., 1952, Wyrazy pochodzenia południowosłowiańskiego w polskich gwarach góralskich, „Język Polski” XXXII, s. 202-208.

Goszczyński S., 1853, Dziennik podróży do Tatrów, Petersburg.

Her I: W. Herniczek-Morozowa, Terminologia polskiego pasterstwa górskiego, cz. 1, Wrocław 1975.

Her II: W. Herniczek-Morozowa, Terminologia polskiego pasterstwa górskiego, cz. 2-3, Wrocław 1976, s. 85-212.

HodSG: S.A. Hodorowicz, Stownik gwary górali Skalnego Podhala, Nowy Targ 2004, ${ }^{2} 2005,{ }^{3} 2013$. KĄśSGO: J. Kąś, Słownik gwary orawskiej, Kraków 2003, ${ }^{2} 2011$.

Kosıński W., 1884, Przyczynek do gwary zakopiańskiej, „Rozprawy i Sprawozdania z Posiedzeń Wydziału Filologicznego Akademii Umiejętności” X, s. 225-309.

Kosıński W., 1877, Słowniczek prowincjonalizmów w okolicach Krakowa, Bochni i Wadowic, „Zbiór Wiadomości do Antropologii Krajowej” I, s. 37-56.

KRYŃsKi A.A., 1884, Gwara zakopańska. Studium dialektologiczne, „Rozprawy i Sprawozdania z Posiedzeń Wydziału Filologicznego Akademii Umiejętności” X, s. 170-224.

Мach: V. Machek, Etymologický slovník jazyka českého, Praha 1968.

MikLosich F., 1886, Etymologisches Wörterbuch der slavischen Sprachenmit Berücksichtigung der anderen indogermanischen Sprachen und Dialekte; mit Nachträgen und einem Index der Wörter, die nicht als Schlagwörter auftreten, Wien.

Младенов С., 1941, Етимологически и правописен речник на бблгарския книжовен език, София.

Nitsch K., 1933, Kościelisko - Polany, „Język Polski” XVIII, s. 137-143.

ODA III: A. Zaręba et al. (red.), Общекарпатский диалектологический атлас, t. 3, Warszawa 1991.

ODA IV: L. Bajog et al. (red.), Общекарпатский диалектологический атлас, t. 4, Львів 1993.

ODA VII: D. Petrović et al. (red.), Общекарпатский диалектологический атлас, t. 7, Београд-Нови Сад 2003.

Reychman J., 1951, W sprawie zapożyczeń węgierskich w polszczyźnie, „Język Polski” XXXI, S. 203-211.

SEBAŃ: A. Bańkowski, Etymologiczny słownik języka polskiego, t. I-II, Warszawa 2000.

SEBor: W. Boryś, Słownik etymologiczny języka polskiego, Kraków 2005.

SEBR: A. Brückner, Słownik etymologiczny języka polskiego, Warszawa 1927.

SEK: W. Boryś, H. Popowska-Taborska, Słownik etymologiczny kaszubszczyzny, t. I-VI, Warszawa 1994-2010.

SESŁ: F. Sławski, Słownik etymologiczny języka polskiego, t. I-V, Kraków 1952-1982.

SGP: Słownik gwar polskich [A - Gnacka], oprac. przez Zakład Dialektologii Polskiej Instytutu Języka Polskiego PAN, Źródła i t. I, red. M. Karaś, J. Reichan, t. II-V, red. J. Reichan, 
S. Urbańczyk, t. VI, red. J. Okoniowa, J. Reichan, t. VII, red. J. Okoniowa, J. Reichan,

B. Grabka, Wrocław-Warszawa-Kraków-Gdańsk-Łódź, 1977-.

SKaRє: J. Karłowicz, Słownik gwar polskich, t. I-VI, Kraków 1900-1911 (t. IV-VI J. Karłowicz i J. Łoś).

Sкок: P. Skok, Etimologijski rječnik hrvatskoga ili srpskoga jezika, Zagreb 1971-1974.

SWOKop: W. Kopaliński, Słownik wyrazów obcych i zwrotów obcojęzycznych z almanachem.

Nowe wydanie, Warszawa 1999.

SWOSoв: E. Sobol (red.), Słownik wyrazów obcych PWN, Warszawa 2002.

SzewCzyк J., 1960, Termin topograficzny „hala” w języku polskim, „Poradnik Językowy” z. 1, S. 36-44.

WET: Z., W. Paryscy, Wielka encyklopedia tatrzańska, Poronin 1995.

WSE-HJP: K. Długosz-Kurczabowa, Wielki słownik etymologiczno-historyczny języka polskiego, Warszawa 2008.

ZвоRSGZ: J. Zborowski, Słownik gwary Zakopanego i okolic opracowany i uzupełniony z materiałów Autora przez Zespół Instytutu Języka Polskiego Polskiej Akademii Nauk pod kierunkiem Joanny Okoniowej, Kraków-Zakopane 2009.

Zejszner L., 1845, Pieśni ludu Podhalan czyli górali tatrowych polskich, Warszawa.

\section{Podhalan vocabulary in A. Bańkowski's Etymologiczny słownik języka polskiego 'Polish etymological dictionary' Summary}

The paper discusses Podhalan vocabulary contained in Andrzej Bańkowski's Etymologiczny słownik języka polskiego (SEBań) 'Polish etymological dictionary'. It scrutinizes the information on the origin of words, and also their dating and other parts of Bańkowski's commentary. By contrasting data from dialectal atlases and dialectal and etymological dictionaries, this author shows that the material found in SEBań is in a large part inaccurate or even erroneous. In the latter case (e.g. oscypek) own explanations have been proposed. 